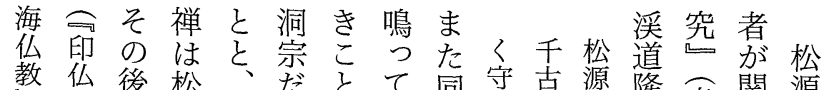
教研後松玉だて 同守克源隆春関源

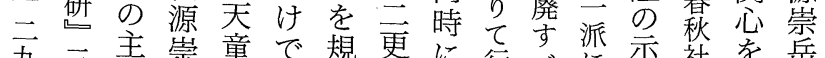
㤂三主崇童で規更に行べに示社を岳 輯三な岳如は定点一ずか僧惄点もは - - 先か浄なし点建べら堂前云つ建 九二研 の 交臨いで圭。ず賛遺八公の寺 尣九究影渉済る—法夸之り。誡主は開 年八は響の宗々曉語覚を専条八鏡山 五 年長があにいに規拾廃点条自鏡の 月年谷 つおうは則遺登坐の第嶌蘭 、百川貝こ松てで四録机禅第に元渓

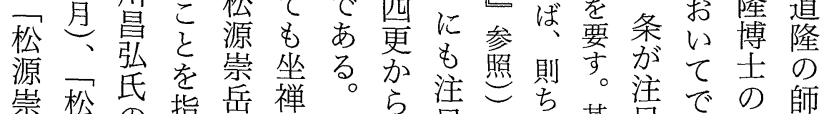

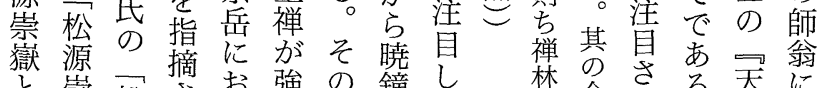

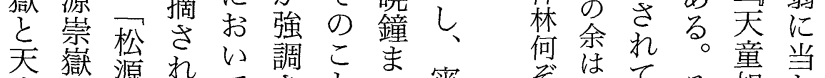

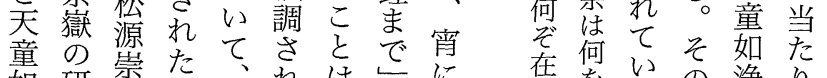

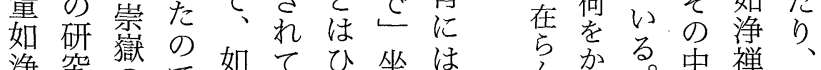
浄究獄で如てひ坐は方市。中禅

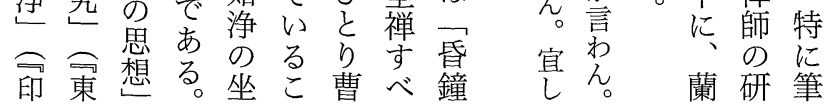

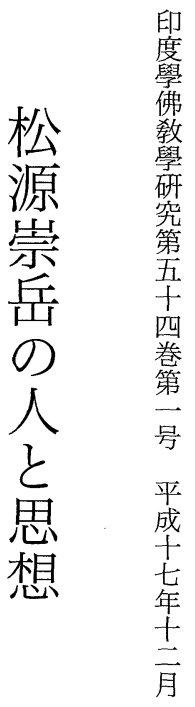

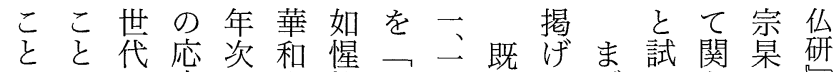
ではで庵を尚撰三九にてずみ心の あ松同裳同塔っ甘八拙お、るが系言

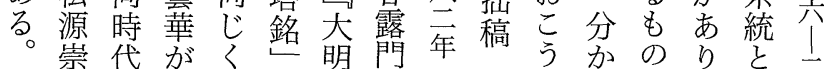

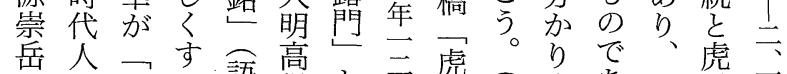

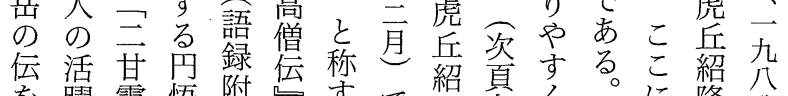
を躍露悟附㐫ず隆参くす隆八 检を門克等まる 指毠㸓松の年 討判等 勤 の摘大照 る るし 称法当る る慧密岳統且

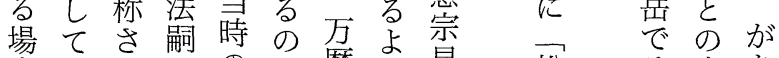
合はれのので暦う杲松香交あ になて大文あ四に源の流げ おらい慧献つ五、狳崇問と ら いなた宗がて年大仏岳題それ

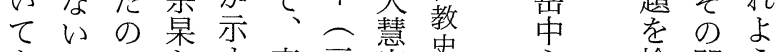

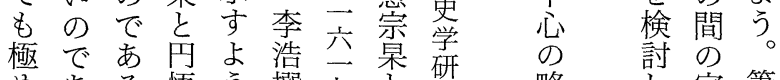
めある悟 う撰 七究究略記宗筆

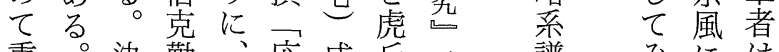
道 重。決勤、忘成丘二譜 みには

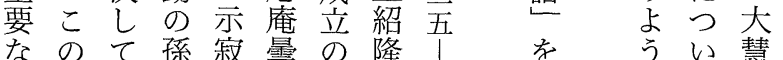


説且て陸てさ従松二こ

は导游明れ来源六と松

松二指既 の明たこ崇九は源

源渭摘に渭吕塔れ獤@言の

崇南古陳南に銘に禅のう伝

岳文孚陳南に銘に禅の記

の文る垣文誤基師刊まを

人隹よ撰集つのづ語本で問

と思のった文い録のも題

思のに釈巻加はてに系なに

想喜】四筆、研の統い卞

石嘉語疑○が東究末及。る

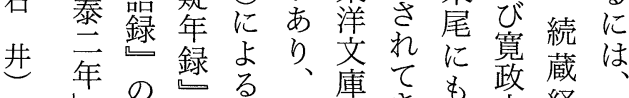

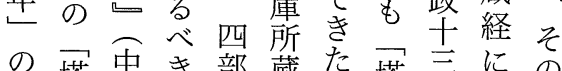

説塔中き部蔵た塔年所の

に銘華で兓のし銘年所塔

明の局ろに種かが公さ銘

らつう收のし種分れ

か嘉一。め五り姇年が福

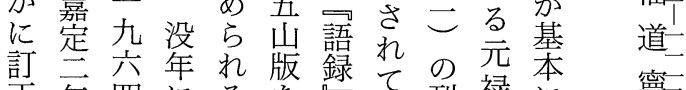

正年四にるを扴禄に

す年関撰含にお本三な

べの三し者め付り、の年る

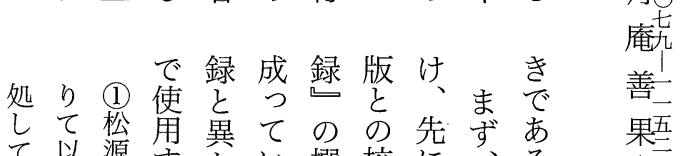

て、以源すない撰校に、る

未自師るるる。者定り伝

嘗号名合略肩を文う記

て。名合略書作う述

嬉幼崇み考き成に会

宕時岳江底はし、るる

ずる。処吉本下先渭に

。已州

稍的

や卓灻泉

長犖家の

じ松

て

世群 呉

のな氏

法らに

䍉ず生

翠臂。

筧。

期注态先鯜当

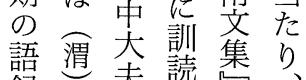

䟿道夫抆

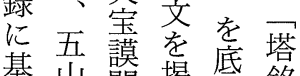

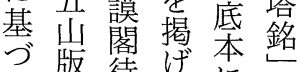

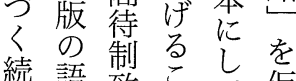

之中经

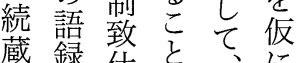

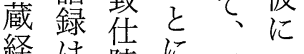

寧

月 $\overrightarrow{0}$

果吾

洪

祖

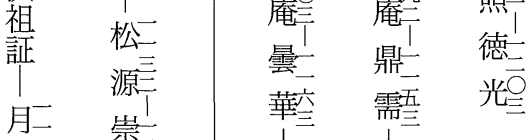

林囬岳总

師

観 無

| 明空

無一慧

門性言

慧一

楊九

岐

方品

会畀

白。

雲五

守0

端

五?

祖

湥四

円○

悟咅

克

勤吾

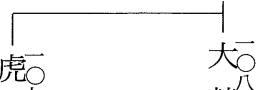

丘慧杂

紹

隆空杲穾

応懶 任

開蘭二

溪三

本○游す種○

は語旗る。種段

道

隆志 


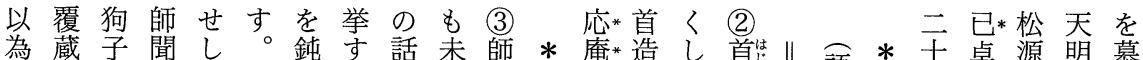

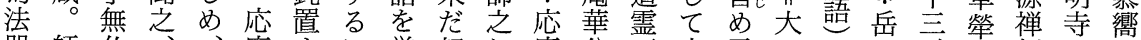

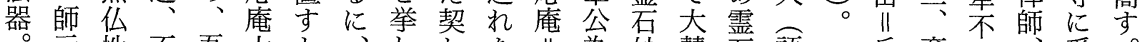

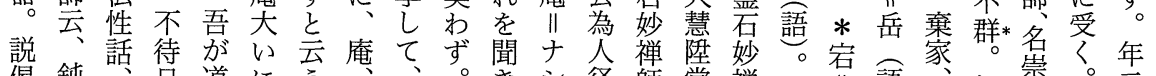

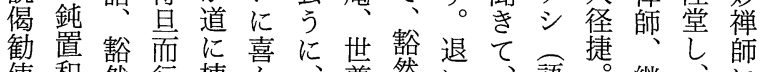

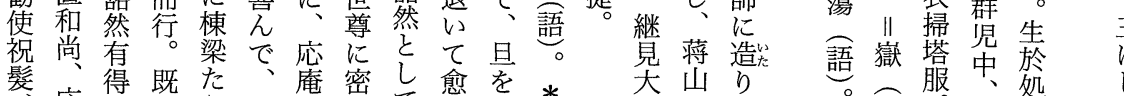

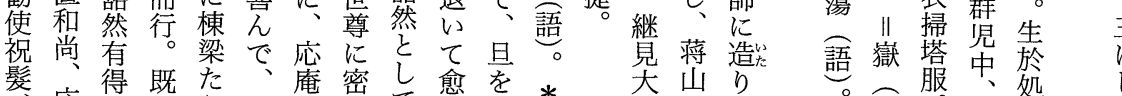

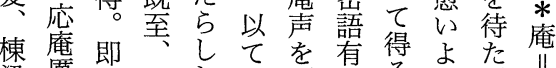

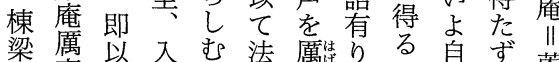
梁䓊萬扣室。器ま蠆り、る自ず菴

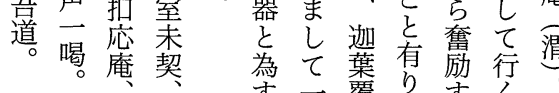

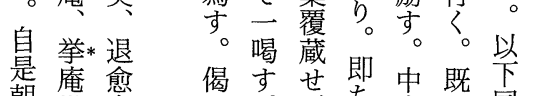

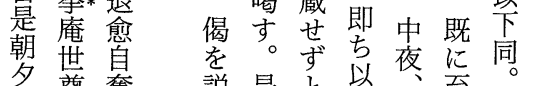

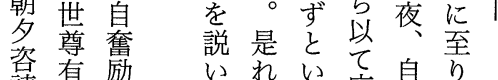

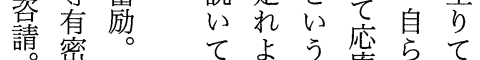
応語中* 勧

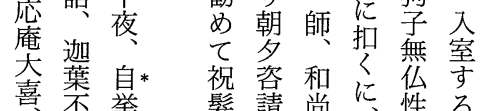

大山 嘒の

慧応継。

禅庵維

師華で

於公大

径の慧

山為 杲

人禪

久径師

之捷に

大な径

慧り 山

垶学に

堂梨見

称。

蒋公
。服中、処

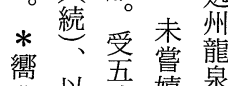

川以五㦳嬉泉

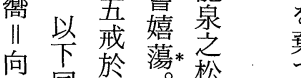

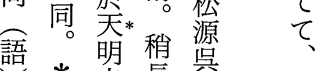
。寺長䒨掃 年 $\|$ 年聞塔 ॥以 世唯服 ナ語法以华 シ語。慕寊衣

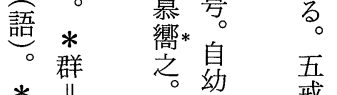

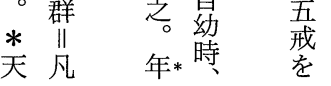

松 源 岳 の 之 思 想 石 井

後*已使秪師有乃頭 えく固師秪こ堆る庆 (5) 門 隆 是 (4)

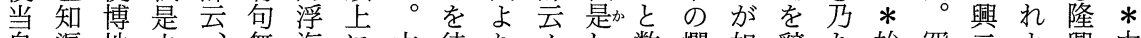

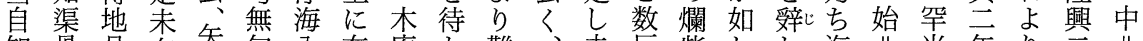
知骨凡在等句入在庵た難、未反柴しし海川当年り云 䯣夫他加閩 手ずし 為在す主とてにナ其、江年終

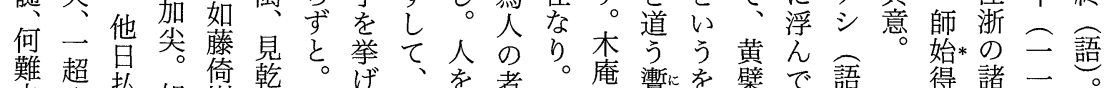
有聖柄是樹元後て

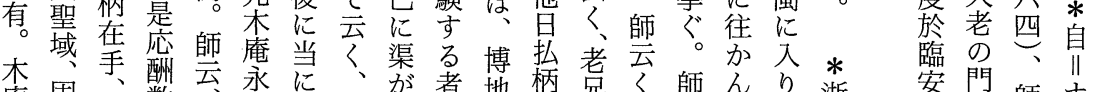

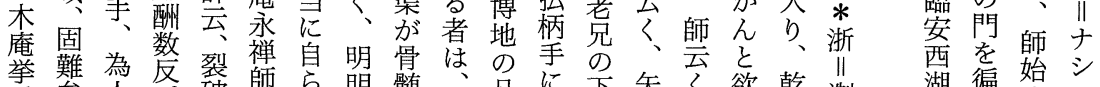

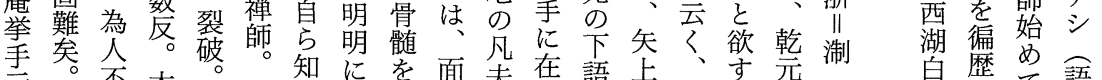

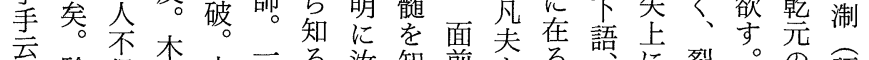

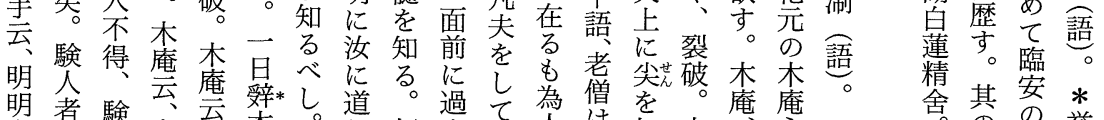

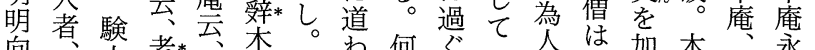

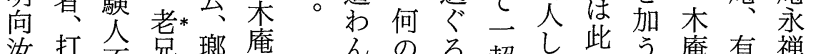
汝打不兄瑯庵んのる超得のう。歶有禅 道向得下瑘欲* 難を超得の。去句師 開面得語道欲* 口き打, 聖す、如是々無に

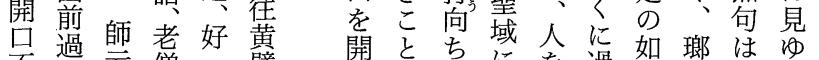

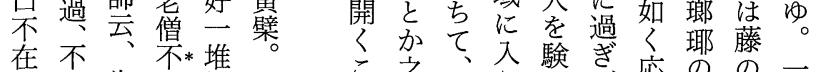
舌待為過爛木 頭開人如柴庵 上只者此渒挙

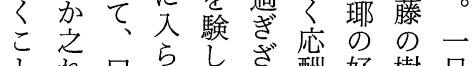
は沓口ら直を得る酬好樹旦 は有を舌ら開导。付るし倚小

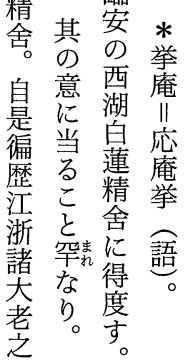


旋こた名為 (7) 密召密切逾にすめ不れ寝密 (6) 出るび山の旋恕* * * 庵云庵於年遷。て是に食庵年 $* *$ 源世。之な治り堂不笑又要今入明、る是李物従を微を不辤 源於人れり。父て虫是川遷今室道見。机庵主笑逾過川

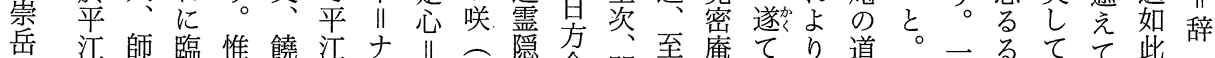

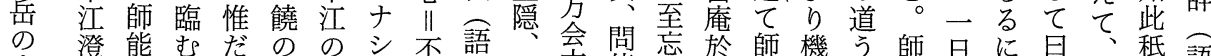

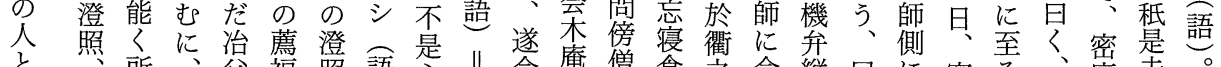

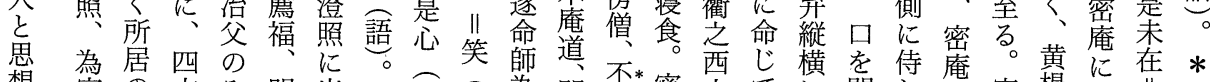

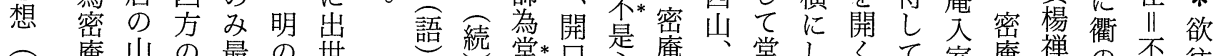

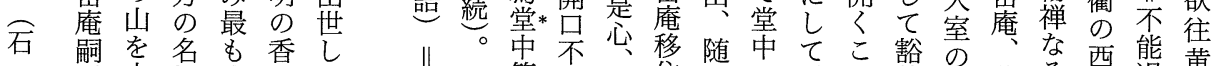

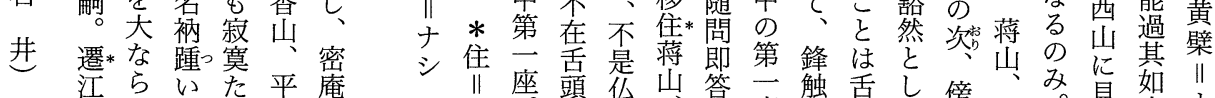
江らて

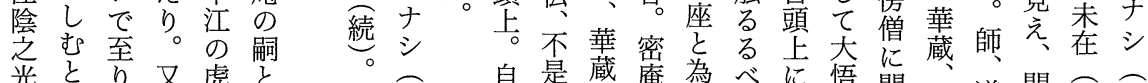

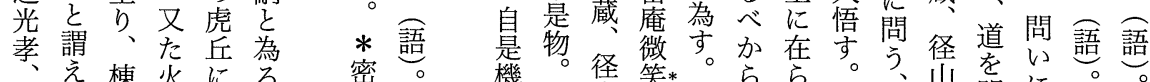
無り宇を遷年密

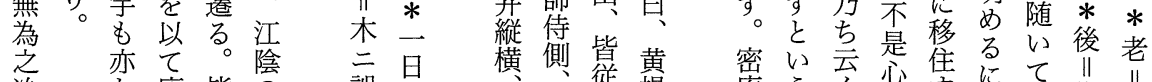
治た廃皆の誤川 父大る。光当

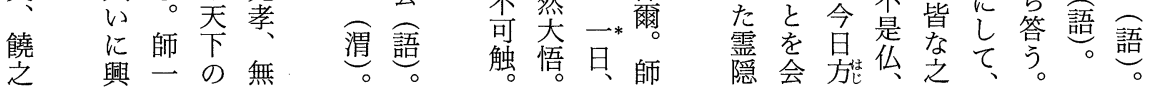

高実因不猶隱驩慶四実にえ頭力ごて持席潮ぞ８，薦 峰嘉書起不之声元十に所る上量と東の而の岳慶 * 廃福 之原泰*偈開廃志潮已全泰無大在人

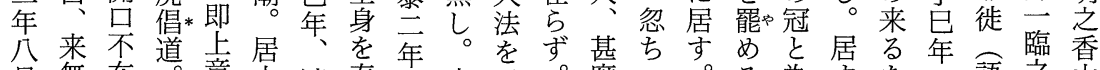

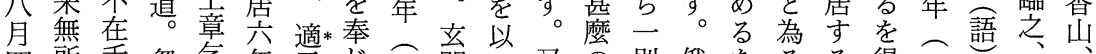

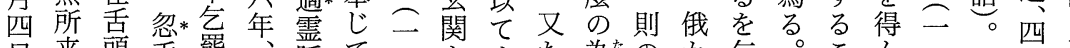

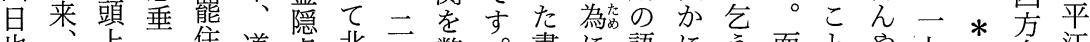

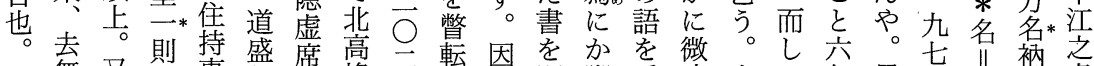

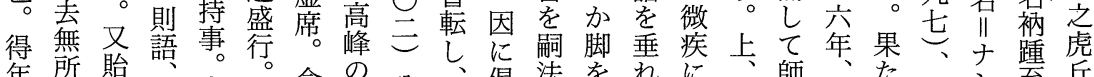

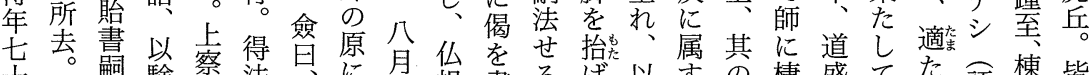

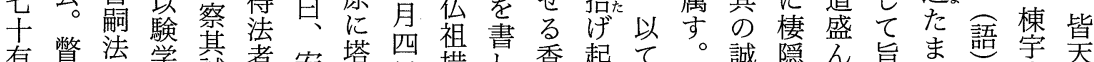

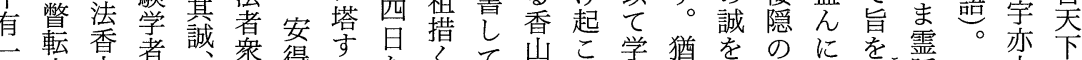

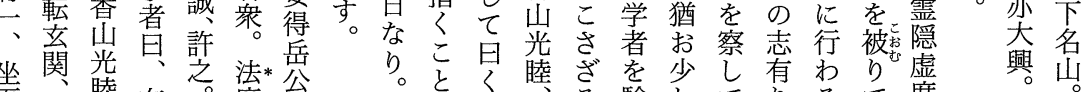

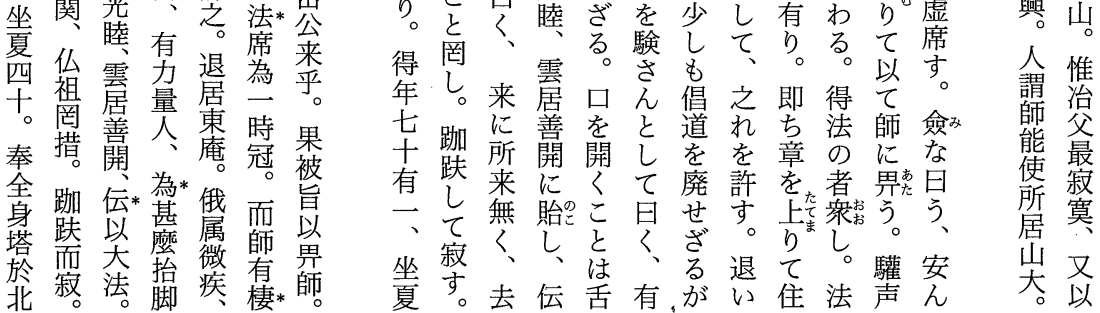


孫軍天率道年塔にの塘に語参浩一遣 (9)

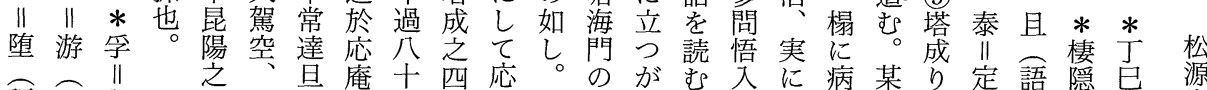
語語敷戦駭旦庵十、四店追濤如む入に病某り定語隠已源

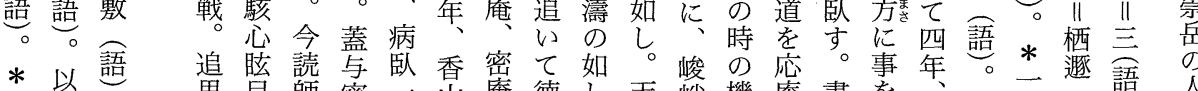

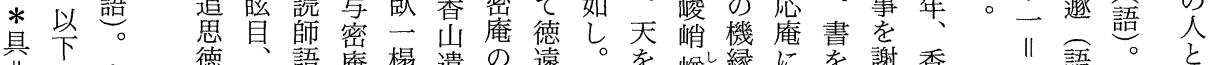

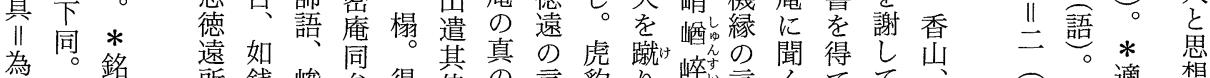

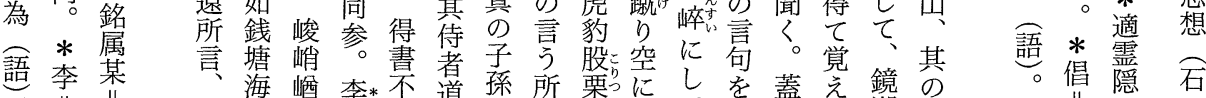

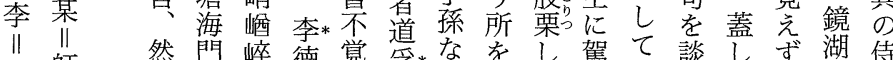

ナ師然門崪徳賞孚*なをし駕て、談しず湖侍

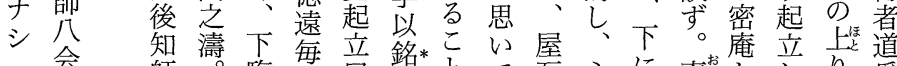

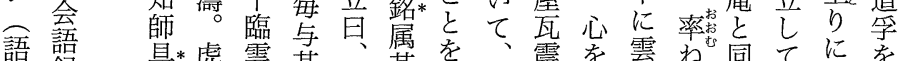

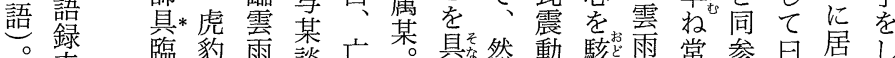

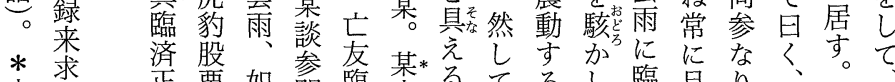

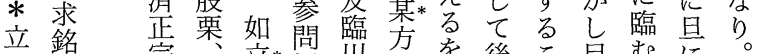

$\|$ 於宗屋立*悟川謝を後こ目むにに。亡年銘

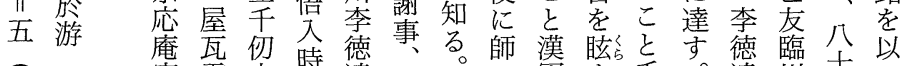

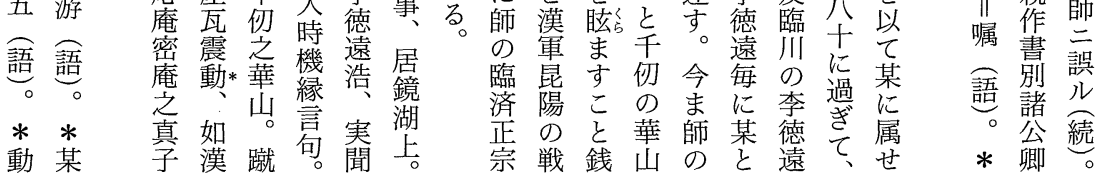

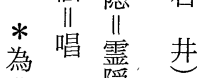

因珸援

語 $*$ 語

* 婴 $*$

伝 忽 法

嘱㤰 畫

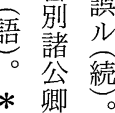

る。なははの松ろ木咸

二示つ多考為源う。庵傑こ摧衆授銘ら後をに金 (10)

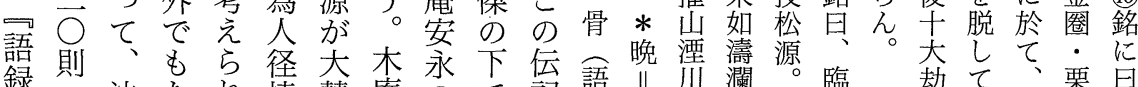

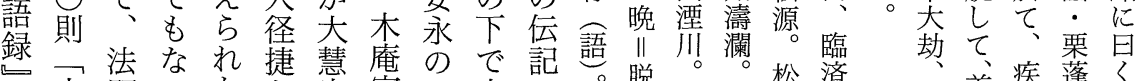

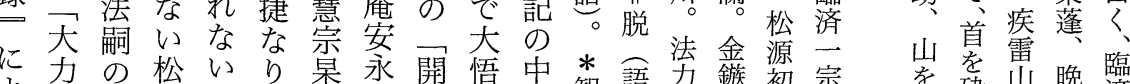

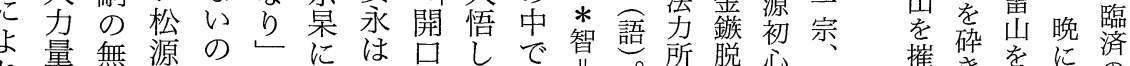

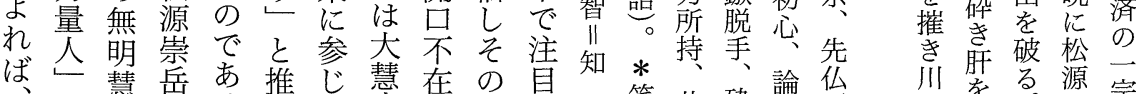
黄性のる。奨た宗舌法守語笑此砕諭企恸をる。源宗 黄話に二。兄時杲頭をべ語川塔鼻渗伝。㴗裂八授先

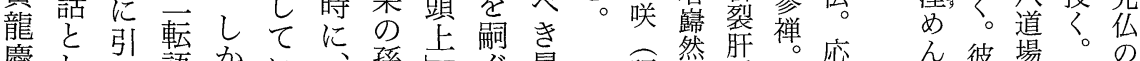

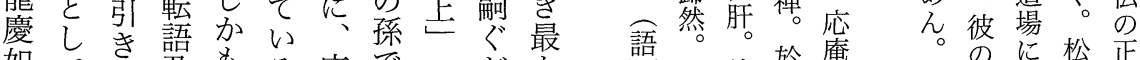
如て継乃も、る応でのがも骂語。彼於庵淠のに松正

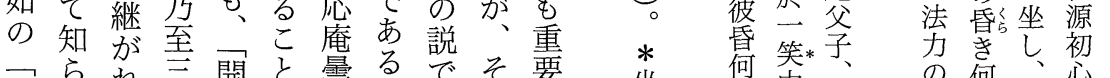

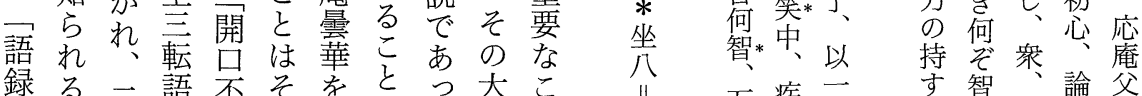

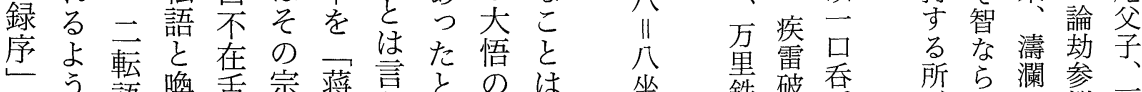
う語喚舌宗蒋言とのは轻鉄破吞所ら瀾参一

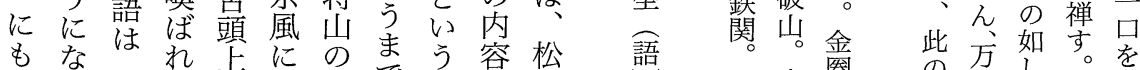
松の無る

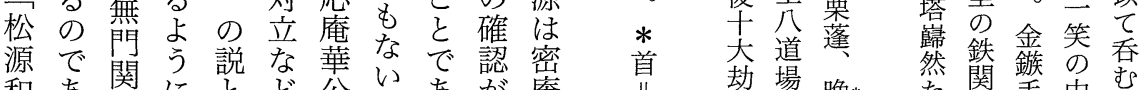

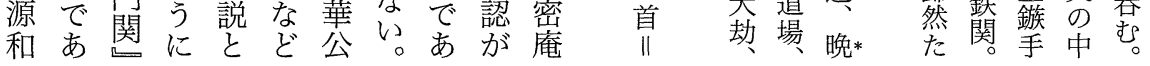




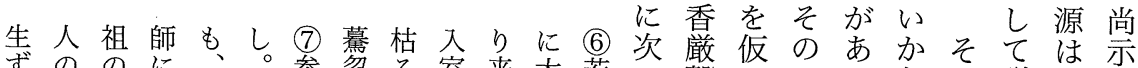

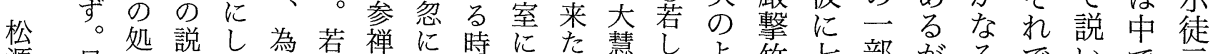
源是別話て人しは非如至り慧此よ竹七部がるでいで云 崇れな机須を何るてや少う悟段は、内はても 岳佗る只学てに方知繁、悟事に道に次そ容松い一明

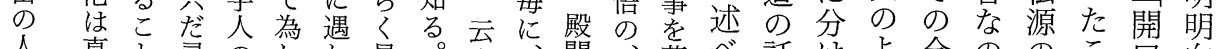

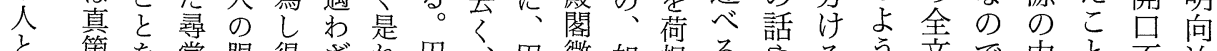
思箇を常眼得ざれ円、円微如担る少るう文で中文不汝

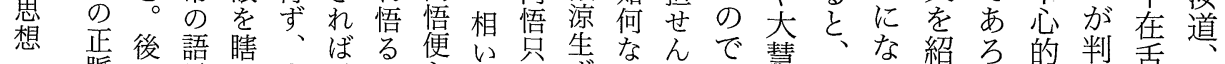

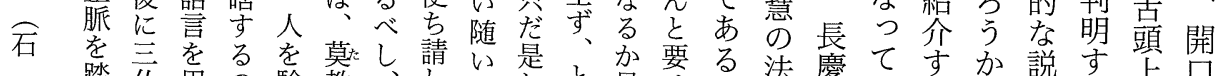

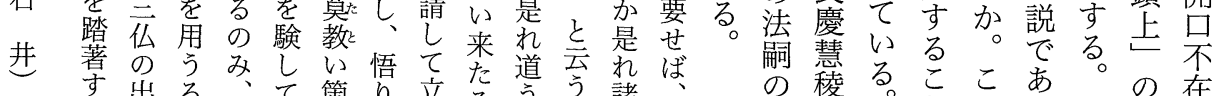

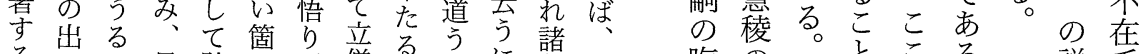

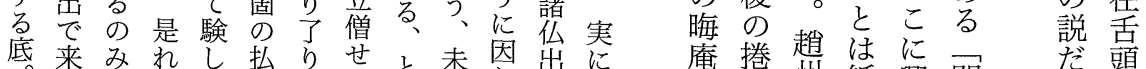

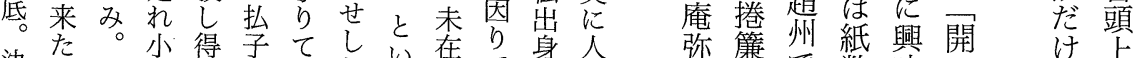

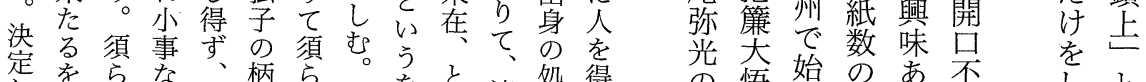

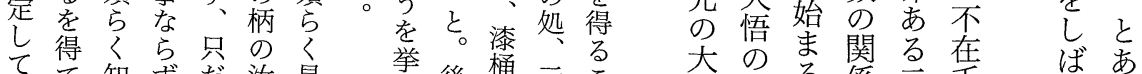

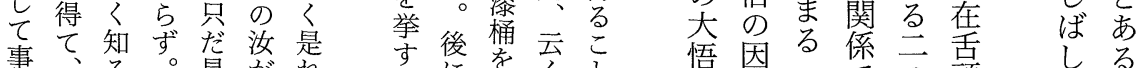

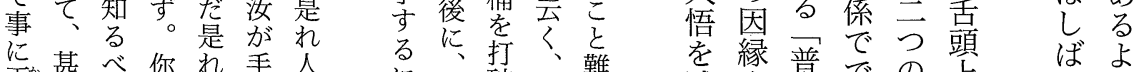

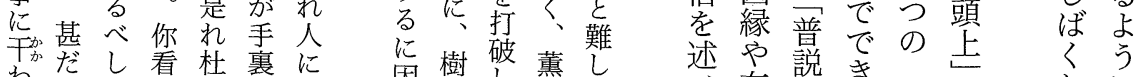

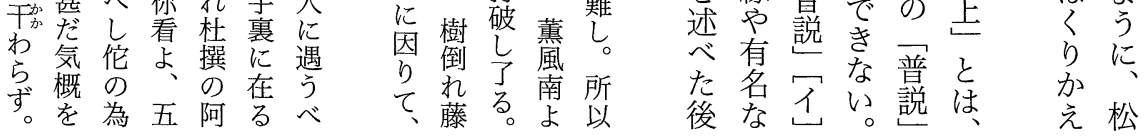

あの仮い公よ悟合知

漫散も則て師まる経にる案つをわらこをず堪惜自也 漫去也公案初ず。験四とのて経されこ著、潮ずしらた なる去過案を案初は㤎段い言為験れるるは潮ず。転如

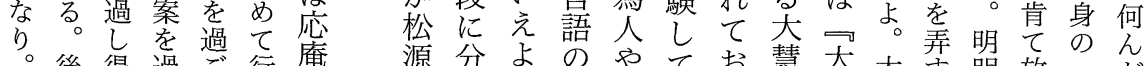

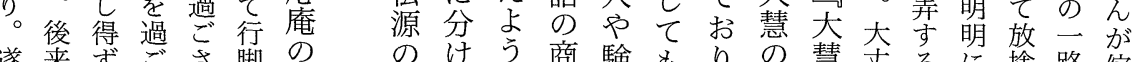
遂来ずごさ脚の公けり。商験もり、の慧丈るに捨路佗

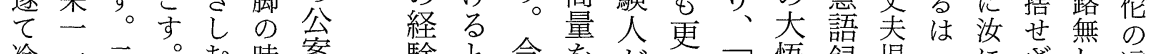
冷二 二

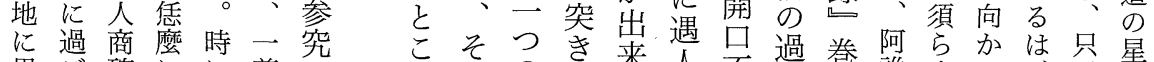

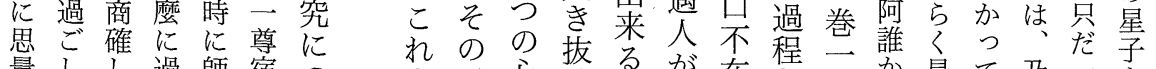

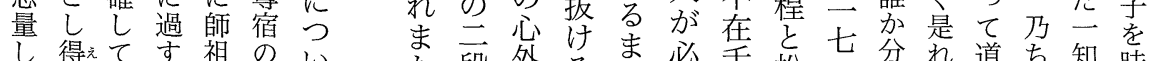
し 得て す祖のい段外る ま必舌松七分れ道ち知昧 て了势学也—会て 重自無真に要頭源无無潮う是半得

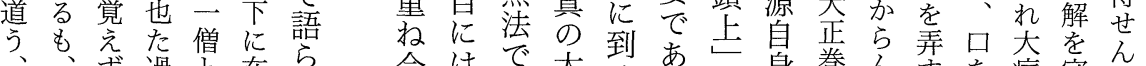

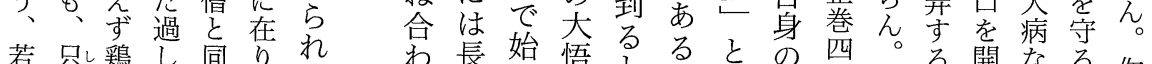

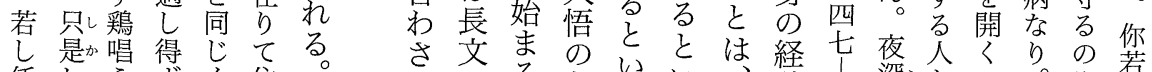

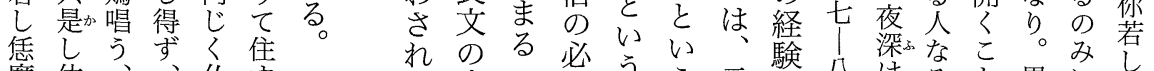

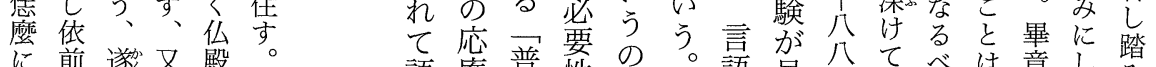
に前遯又殿。語庵普性ので多語見公久べは竟し踏

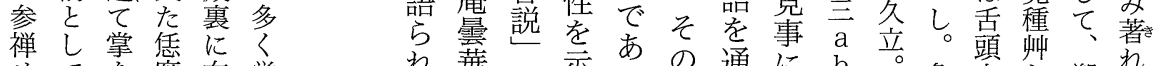
せてを麼在学机華示主の通に

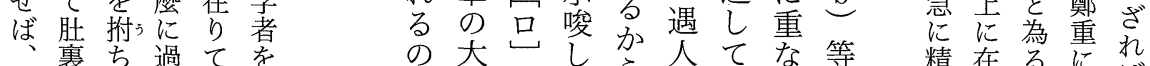
如黒てすで悟をてら、に大りで彩售るに宝ば 
斤

のこ計を多般ち佗く忙櫋し在此が虎さのる判守

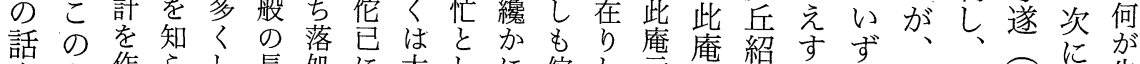
やよ作らし長処に大しに佗し元に隆れれ虎更二曹生 南うすずて老を知事て到の時和参にばも丘に○洞死

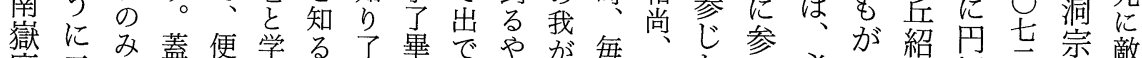

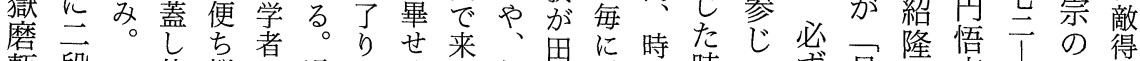

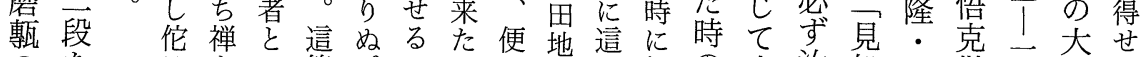

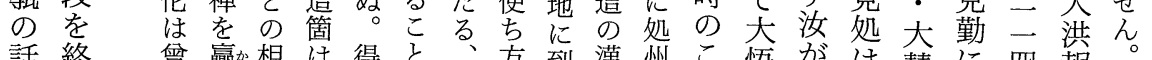
話終曾贏加相は得と方到漢州こ悟がは慧に四報

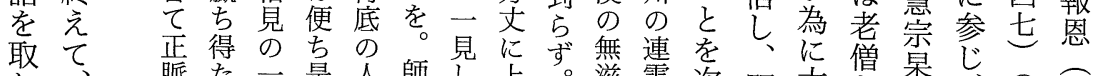

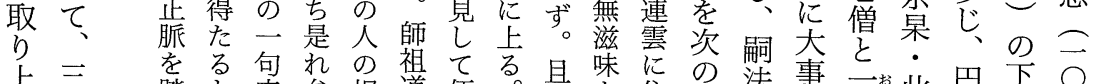

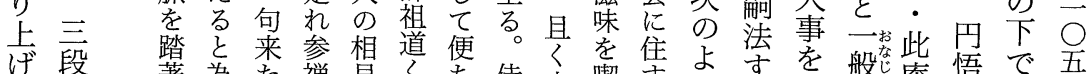

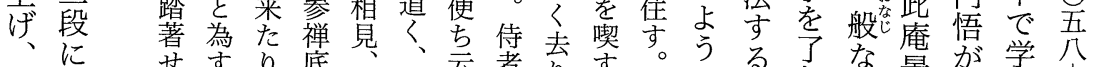

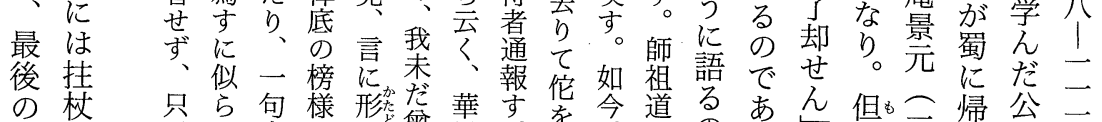

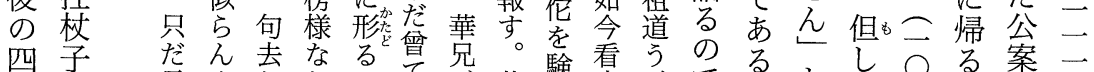

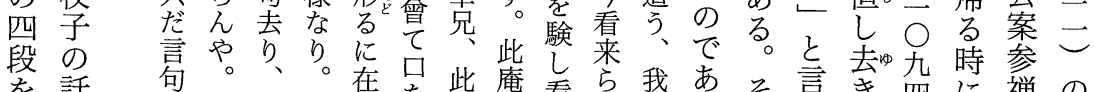

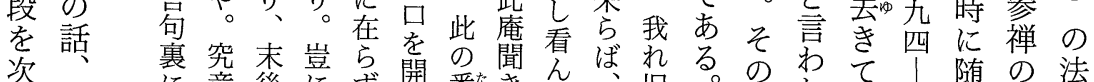

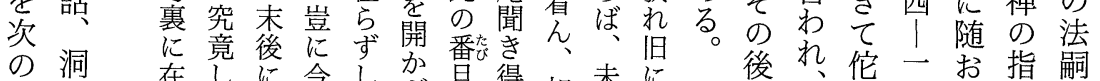

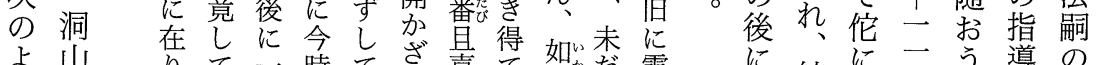

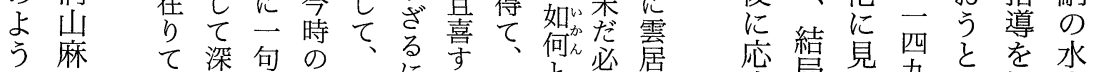

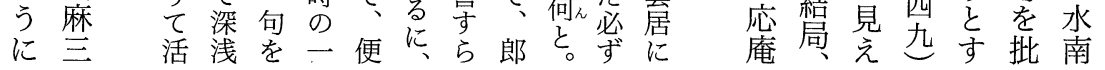

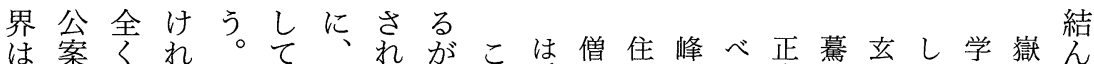
言が公ばつ、佗て、の舌今需頂し宗然にて、得上で 語使案なま便已い上普頭夜る情る化をと停箱座い に用をらり、ちにるに説卡情こ立則滅しま箘却る 留さ使な、落知と紹の在尽難ばち却て ら失ず夏得筒の

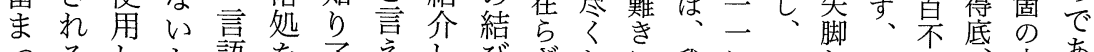
つるしと語を了えしびざしに我に一し心知方方あ てのないに知りよたにるてるれれ紉切てに悟便る。 はでいう出るぬう。二もこ道ら便素人踏恃势得有

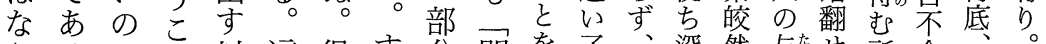

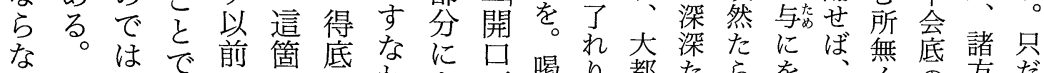

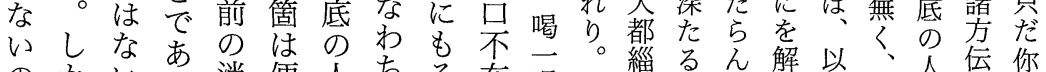
のかいる消便人ち、そ在喝須綉海兄解以、人伝你

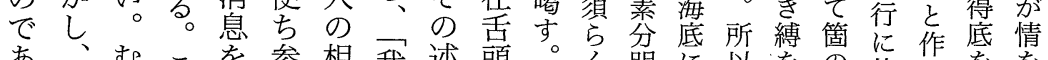

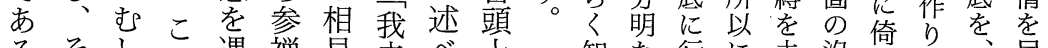
るとしれ遇禅見未先上知な行に去沒る 、尽

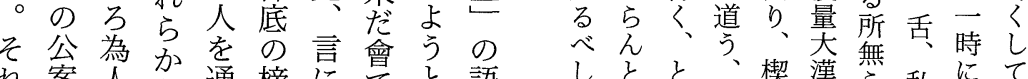

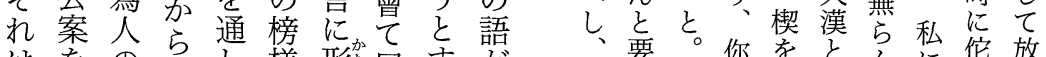

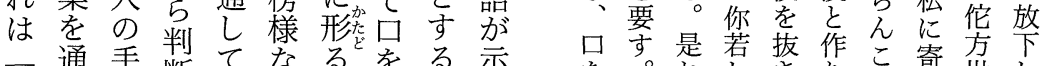

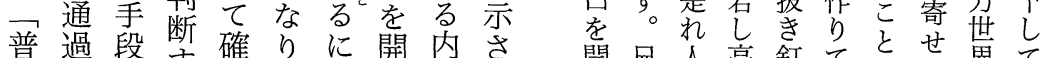

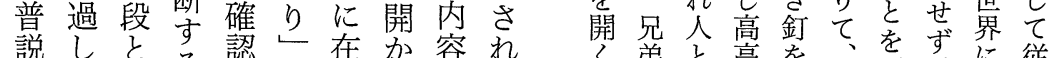

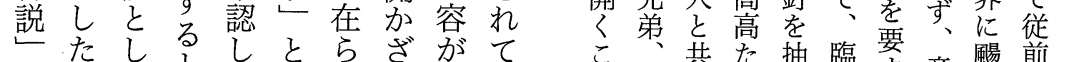

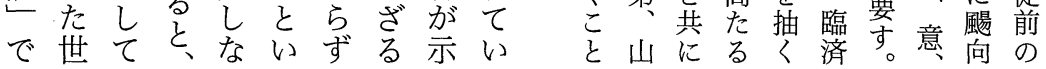


松
源
䍃
の
令
思
想
石
井

な現識楊詳明のるすす塔こる松と源度

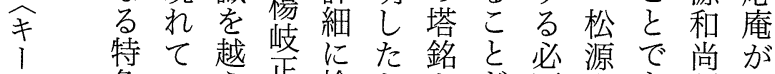
ワ色い艺哌検とをだ要崇あ語い

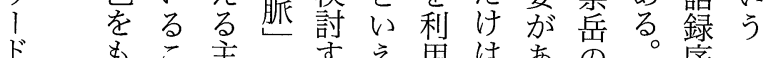

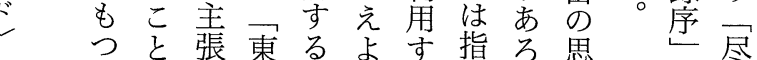
永松のでが山必うる摘う想 か間な正要。必でがを地 は違か脈が松、要き、検う是

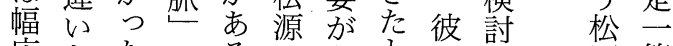

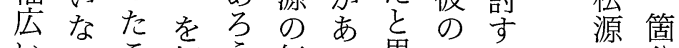

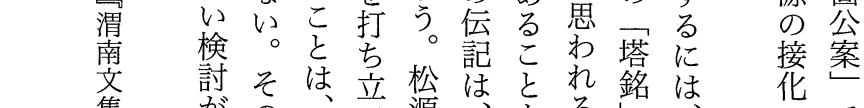
駒隹㤎の宗語た源更もる。銘は、华で 澤開後風録の岳に語そ重だ本り

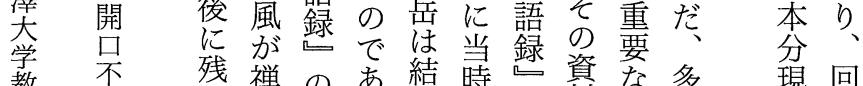
教不残禅のあ結時恣資な多現回 授在さ思いり局のと料分く成庵 文頭て想たそは禅のは析の公譙

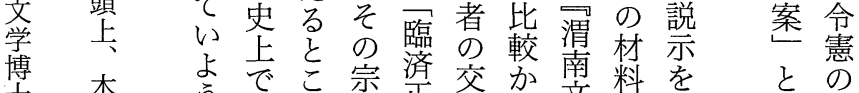

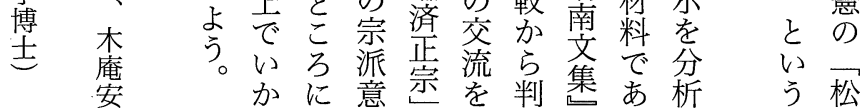
かに意宗を判集市析 
Taishō Canon vol.14. Therefore, in this paper I have researched the Vimalakirtinirdeśa text dated close to the time of Zhiyi, as far as the eighth chapter. On the basis of this research, I was able to point out areas with particular relevance to Zhiyi.

\section{Songyuan Chongyue: His Biography and Thought}

Shūdō ISHII

In this article I have re-examined the stūpa inscription for Songyuan Chongyue (松源崇岳), which was written by Lu You (陸游) and included in his Weinan Anthology. According to the inscription, Songyuan was enlightened upon hearing Mi'an Xianjie's (密庵咸傑) instructions on Muan Anyong's (木庵安永) phrase, “opening one's mouth is not on the tongue.” Muan Anyong was a second-generation successor to Dahui (大慧). Afterward, this phrase came to represent Songyuan's teaching. The phrase's meaning is examined on the basis of two of his general lectures (普説), in which both the experience of great enlightenment based on the kōan and having an encounter with a good Zen master are important. Thus this kōan becomes referred to as "a single kōan that exhausts the great earth" and "the kōan of the immediate manifestation of one's original allotment."

\section{Shenhui’s (神會) Bodhisattva-śíla Thought}

Shirō NAKAJIMA

Parallelisms between the early stage of Chan Buddhism (禅宗) and the Mahāyāna-Bodhisattva-śíla Movement (大乗菩薩戒運動) have been pointed out. Northern Song Chan's (北宗) Wushen Fangbian men (『無生方便門』), Shenhui's Platform-Words (『壇語』), the Lidai fabao ji and the Dunhuang Platform Sūtra of the Sixth Patriarch (敦煌本『六祖壇経』)"〈Mind-groundFormless-śila (心地無相戒)〉 record the giving and receiving of the Mahāyāna-Bodhisattva-CIla according to the rites prescribed in the Fanwang jing ( $『$ 梵網経』) since the Fourth Patriarch Daoxin (四祖道信). That Shenhui's Plat- 